\title{
Naxcıvan Muxtar Respublikasında Dövlət Gənclik Siyasətinin Osasları
}

\author{
DOI: $10.26466 /$ opus. 385418
}

\section{Flora Oləsgərova* - Cavadxan Qasımov**}

* Doç. Dr., Azərbaycan Dövlət Turizm və Menecment Universitetinin dekan müavini, iqtisad üzrə fəlsəfə doktoru Nahcivan

E-Posta: flora aleskerova@mail.ru

ORCID: 0000-0002-7430-6411

${ }^{* *}$ Doç. Dr., AMEA Naxçıvan Bölməsi, Təbii Ehtiyatlar İnstitutunun İqtisadiyyat şöbəsinin böyük elmi işçisi, iqtisadi üzrə fəlsəfə doktoru, Nahcivan E-Posta: cavadxan.yusifoglu@mail.ru

ORCID: 0000-0002-3826-033X

\section{Öz}

Naxçıvan Muxtar Respublikası ölkəmizdə hayata keçirilan milli təhsil siyasatinin uğurlu davamını tamin etmakdadir. Osasları ümummilli lider böyük Heydar Oliyev tarafindan qoyulan bu faaliyyat dövlatin sosial siyasatinin on mühüm ünsürüdür. Gonclarin savadlanmasl, elmi bilik vo tacrübalarinin artması müasir dünya elmina inteqrasiya olunması sahasinda qatiyyatli addımların ifadəsi vo tasdiqidir. Bu istiqamotda Naxçıvan Muxtar Respublikasında iqtisadiyyatın sosiallaşmasının an mühüm göstaricilarindan biri kimi ganclara dövlat qayğısının güclandirilmasi va bu istiqamatda dövlat siyasatinin müayyanlaşdirilmasindan ibaratdir. Qeyd edək ki, muxtar respublikada dövlat ganclar siyasətinin asasları güclü iradə asasında müəyyən edilmişdir. Aydındır ki, muxtar respublikada gənclarin müasir təhsil imkanlarından yararlanmaq və dünyagörüşünün artırılması sahəsindəki faaliyyətin təşkili sahəsində aşă̆ıdakı hüquqi va sosial əhəmiyyəti yüksək olan tanzimlamalar hayata keçirilmişdir.

Açar sözlər: Dövlat Gənclar siyasati, müasir təhsil sistemi, sosial siyasat, bilik va təcrübə, dünya elmina inteqrasiya vas.

OPUS (c) Uluslararası Toplum Araştırmaları Dergisi-International Journal of Society Researches ISSN:2528-9527 E-ISSN : 2528-9535

http://opusjournal.net 


\title{
Fundamentals of State Youth Policy in Nakhchivan Autonomous Republic
}

\begin{abstract}
Nakhchivan Autonomous Republic provides a successful continuation of the national education policy implemented in our country. This activity, laid by the great national leader Heydar Aliyev, is the most important element of the state's social policy. The advancement of young people, the increase of their scientific knowledge and experience are an expression and confirmation of decisive steps in the integration of modern science into the world science. The most important indicators of the socialization of the economy in Nakhchivan Autonomous Republic are the strengthening of the state care for young people and the determination of the state policy in this direction. It should be noted that the basis of state youth policy in Autonomous Republic was determined on the basis of strong will. Obviously, in the Autonomous Republic, the following legal and social significance arrangements have been made in organizing activities for young people to benefit from the modern educational opportunities and to enhance their outlook.
\end{abstract}

Keywords: State Youth Policy, modern education system, social policy, knowledge and experience, integration into world science, etc. 


\section{Giriş}

Naxçıvan Muxtar Respublikasında iqtisadiyyatın təminat qabiliyyətli, sosialyönümlü olması və perspektivlərə hesablanması məqsədilə sistemli tədbirlər həyata keçirilməkdədir. Bu özünü bütün sahələrlə yanaşı, həm də təhsil sahəsində də göstərməkdədir. Təhsil isə, təbii ki, ölkənin səmərəli sosial siyasətinin də əsas istiqamətlərinin tərkib hissəsi kimi hər zaman öz aktuallığını qorumaqdadır. Sosial siyasət - dövlətin daxili siyasətinin əsas hissəsi olub, dövlətin sosial proqramlarında ifadə olunur və praktikada həyata keçirilir, əhalinin sosial qruplarının mənafeyi naminə və maraqları vasitəsilə cəmiyyətdə olan münasibətləri tənzimləyir (Qasımov C.Y. 2017, s. 80).

Muxtar respublikada təhsilin və tədrisin keyfiyyətinin yüksəldilməsi üzrə proseslərin səmərəliliyinin təmin edilməsi, təşkili və idarə olunması məqsədilə Naxçıvan Muxtar Respublikası Ali Məclisinin Sədri tərəfindən ardıcıl olaraq hüquqi tənzimləmələr həyata keçirilmişdir:

- 31 yanvar 2012-ci il tarixdə Naxçıvan Muxtar Respublikasında gənc istedadlara dövlət qayğısının artırılması haqqında imzalanan Fərman və bu Fərmanla təsdiq edilən Naxçıvan Muxtar Respublikasında Gənc İstedadlarının "Qızıl Kitabı"na adları yazılmış gənc istedadlar üçün təqaüdün verilməsi Qaydaları (Ohmədov N.H., 2008, s. 107);

- 20 iyun 2014-cü il tarixdə Naxçıvan Muxtar Respublikasının təhsil müəssisələrində elektron təhsilin təşkili ilə bağlı əlavə tədbirlər haqqinda Sərəncam;

- 23 avqust 2014-cü ildə “Elm, texnika, memarlıq, mədəniyyət və ədəbiyyat üzrə Naxçıvan Muxtar Respublika mükafatlarının təsis edilməsi, Mükafat Komissiyasının yaradılması və Osasnaməsinin təsdiq olunması haqqinda" Fərman (Qasımov C.Y., 2017, s. 25);

- 4 sentyabr 2014-cü ildə "Naxçıvan Muxtar Respublikası Ali Məclisinin Sədri yanında Bilik Fondunun təsis edilməsi haqqında" Fərman;

- 14 mart 2015-ci il tarixdə “Naxçıvan Muxtar Respubli-kasının elm, ali və orta ixtisas təhsili müəssisələri ilə ümumtəhsil məktəbləri arasında əlaqələrin təşkili haqqında" Sərəncam; 
- 27 iyul 2015-ci ildə "Ali və orta ixtisas təhsili müəssisələrində ixtisasların müvafiq təşkilatlara hamiliyə verilməsi haqqında" Sərəncam və s (http://www.e-qanun.az).

$\mathrm{Bu}$ hüquqi aktlar muxtar respublikada təhsil və tədrisin səmərəliliyinin yüksəldilməsində elmlə təhsilin vəhdətinin təşəkkülündə, müasir dünya təcrübəsindən istifadədə, təhsil prosesində innovativ inkişafın stimullaşdırılmasında, ixtisaslı kadrların hazırlanmasında, təhsil sahəsində ölkənin hədəflədiyi inkişaf səviyyəsinin təmin edilməsində güclü təkandır. Eyni zamanda bunlar ölkənin dinamik sosial-iqtisadi inkişafının mühüm göstəricilərini ifadə etməkdədir. Sosial-iqtisadi inkişaf - əsasən uzunmüddətli dövrlər üçün xarakterik olub, cəmiyyətin sosial və iqtisadi sahədəki məsələlərinin düzgün istiqamətləndirilməsini və onların səmərəli həlli yollarını özündə əks etdirməklə, dövlət tərəfindən tənzimlənmənin xüsusi formasını ifadə edir (Ohmədov N.H., 2008, s. 67).

Azərbaycan xalqının ümummilli lideri Heydər Oliyevin əski Sovetlər Birliyi dönəmində, yəni 1970-1980-ci illərdə ölkəmizə rəhbərlik etdiyi zamanlarda Naxçıvan Muxtar Respublikasında təhsil sektorunda güclü təşkilatlanma təmin edilmiş, onun səmərəlilik və keyfiyyət göstəriciləri yüksəldilmişdir. Mənbələrə diqqət edəndə aydın olur ki, göstərilən illər üzrə muxtar respublikada müvafiq olaraq 59059 və 65389 şagird təhsil almışır. Həmin dövrlərdə müəllimlərin sayı isə 3120 və 5410 nəfər təşkil etməkdə idi (Naxçıvan Muxtar Respublikası 75., 1999. yubiley-statistik məcmuə., s. 47). Təbii ki, bunlar dövlətin müasir gənclik siyasətinin davamlı inkişafı üçün baza rolunu da oynamaqdadır.

\section{Müasir Dövrdə Gənclər Siyasətinin Perspektivleri}

Araşdırmalar göstərir ki, muxtar respublikada dövlətin gənclik siyasəti onun təhsil və savadlanma məqsədlərinə xidmət edərək, ölkənin makrosəviyyədəki sosial dayanıqlığının çox mühüm elementlərinə çevrilmişdir. Təhsil səviyyəsinin artırılmasına xidmət edəcək infrastrukturun təşəkkülü burada müasir standartların tətbiqinə şəraitin yaradılmasında stimullaşdırıcı amil olmuşdur. Qeyd edək ki, hələ 1995ci ildən başlanan bu proseslər təhsil sektorunun kəmiyyət və keyfiyyətini 
irəliyə doğru dəyişmişdir. İnfrastrukturun gücləndirilməsinə çevik təsir edəcək bu amillər nəticəsində artıq 2001-ci ilin sonlarına yaxın muxtar respublikada daimi məktəbəqədər uşaq müəssisələrinin sayı 106 (o cümlədən, şəhər yaşayış məntəqələrində 27 , kənd yerlərində 79 olmaqla), daimi məktəbəqədər uşaq müəssisələrində uşaqların sayı 4636 (o cümlədən, şəhər yaşayış məntəqələrində 1665, kənd yerlərində isə 2971) olaraq göstərilə bilər (Müstəqilliyimizin on ili, 2001, s. 67).

Keçən müddət ərzində Naxçıvan Muxtar Respublikasında dövlət siyasətinin çox mühüm hissəsini təşkil edən gənclərin vətənpərvərlik ruhunun yüksəldilməsində, onların ixtisaslaşdırılmış kadr potensialının tərkib hissəsinə çevrilməsində və milli iqtisadiyyat quruculuğundakı fəaliyyətlərinin sürətləndirilməsində mühüm tədbrilər planları həyata keçirilməkdədir. Bunun tərkib hissəsi olaraq, hazırda Naxçıvan Muxtar Respublikasında böyüyən sağlam gənclik məhz bu ideyalar əsasında yetişməkdədir. Eyni zamanda bütün bunlar muxtar respublikada təhsil sektorunun güclü potensial əsasında qurulduğunu göstərməkdədir. Qeyd edək ki, burada:

- 3507 uşağın qayğı ilə əhatə olunduğu 19 məktəbə qədər təhsil müəssisəsi;

- 44782 şagirdin təhsil aldığı 217 əyani ümumtəhsil müəssisəsi;

- 426 şagirdin təhsil aldığ1 4 peşə məktəbləri və peşə liseyi;

- 1770 tələbənin təhsil aldığ 3 orta ixtisastəhsil müəssisəsi;

- 6419 tələbənin (5444 tələbə dövlət, 975 qeyri-dövlət) təhsil aldığ 3 (2-si dövlət, 1-i qeyri dövlət) ali təhsil müəssisəsi fəaliyyət göstərir (Qasımov C.Y., Oləsgərova F.Q., 2017, s. 35).

Naxçıvan Muxtar Respublikasında sosial dayanıqlığın ən mühüm göstəricilərindən birini iqtisadiyyatın bütün sahələrində innovativ inkişafın geniş əhatə dairəsini formalaşdırması təşkil etməkdədir. Bu amil təhsil sahəsində həyata keçirilən tədbirlərin ən gerçək ifadəsinə çevrilmişdir. Qeyd edək ki, savadlanmanın, elmi-nəzəri biliklərin, dünyagörüşün və məntiqi yanaşmanın təkanverici qüvvəsinə çevrilən tədbirlər muxtar respublikada təhsil səviyyəsinin yüksəldilməsində ciddi amil olmuşdur. Bunu aşağıdakı cədvəl də ifadə etməkdədir (http://www.statistika.nmr.az/). 
Cədvəl. 2015-ci ildə Naxçıvan Muxtar Respublikasının ümumtəhsil məktəblərinin ÍKT ilə təminatı Dars ilinin avoalina

\begin{tabular}{|c|c|c|c|c|}
\hline \multicolumn{2}{|r|}{ Göstəricilər } & Şəhər & Kənd & Ümumi \\
\hline 1 & Ümumtəhsil məktəblərinin sayı & 36 & 181 & 217 \\
\hline 2 & $\begin{array}{l}\text { Kompüteri olan ümumtəhsil } \\
\text { məktəblərinin sayı }\end{array}$ & 36 & 181 & 217 \\
\hline 3 & $\begin{array}{l}\text { İnternetə çıxışı olan } \quad \text { ümumtəhsil } \\
\text { məktəblərinin sayı }\end{array}$ & 36 & 181 & 217 \\
\hline 4 & Kompüterlərin (fərdi, noutbuk və s.) sayı & 1280 & 2521 & 3801 \\
\hline 5 & İnternetə qoşulan kompüterlərin sayı & 1094 & 2159 & 3253 \\
\hline 6 & $\begin{array}{l}\text { Orta hesabla bir kompüterdən istifadə } \\
\text { edən şagirdlərin sayı }\end{array}$ & 14 & 11 & 12 \\
\hline
\end{tabular}

Cadval Naxçıvan MR Dövlat Statistika Komitasinin materialları asasında müalliflar tarafindan hazırlanmışdır.

\section{Gənclər İstehsal Münasibətlərinin Hərəkətverici Qüvvəsi Kimi}

Qeyd edək ki, elmi əsaslandırmalar baxımından ümumtəhsil məktəbləri uşaq və gənclərə təhsil verən, onların hərtərəfli inkişafını və estetik tərbiyəsini həyata keçirən müəssisələrdir (Azərbaycan Respublikası Dövlət Statistika Komitəsi. 2004, s. 54). Buradan da görünür ki, ümumtəhsil məktəbləri cəmiyyətin həyati və mənəvi keyfiyyətlərinin inkişafında çox zəruri və həlledici amildir. Çünki məqsədyönlü təhsil cəmiyyətin inkişaf dinamikasının hərəkətverici qüvvəsi olub, qarşıdakı uzaq gələcək üzrə aktuallığını qoruyan səmərəli istehsal münasibətlərinin zəruri tənzimləyicisi rolunu oynamaqdadır. Şübhəsz ki, bütün bunlar gənc nəslin mədəni səviyyəsinin daha da yüksək səviyyəli inkişafına istiqamətlənib. Burada həm də güclü təcrübəyə malik olmaqla müasir istehsal mədəniyyətinin mövcudluğuna köklənən proseslərin təşkilinə önəm verilir. İstehsal mədəniyyəti dedikdə, onun texniki-iqtisadi, təşkilati və estetik səviyyəsinə olan normativ tələblərin məcmusu başa düşülür (Libman Q.I.ं, Filatov O.K. (1989).

Sosial-iqtisadi inkişafın artan dinamikası təhsil sektorunun davamlı yüksəlişini təmin etməklə Naxçıvan Muxtar Respublikasında gənc nəslin müasir dünyanın elmi yeniliklərinə münasibətində, düzgün yanaşmasında və səmərəli nəticələrin ortaya qoyulmasında mühüm 
əhəmiyyət daşımaqdadır. Müasir dövrün elmi tədqiqatlarının, təhsil sahəsindəki ən son nailiyyətlərinin əldə edilməsi məhz bu istiqamətdə təmin edilən innovativ potensialın əhatəsindən və imkanlarından çox asılıdır. Buna görə də təhsil sahəsində, eləcə də ümumtəhsil məktəblərində kompüterləşmə səviyyəsinin, internetdən istifadə imkanlarının səmərəliliyi geridə qoyduğumuz illərin məhz sosial-iqtisadi ininkişaf tarixinə aid edilməlidir. Qeyd edilən proseslər muxtar respublikada həm də insan potensialının hazırkı şəraitdə inkişafından ibarət olub, qarşıdakı dövrlər üzrə yüksək perspektivlərə söykənən hədəflərini də müəyyən etməkdədir. İntellektual mülkiyyətin bazar münasibətlərinin mühüm təzahür fosmalarından biri kimi əhatə dairəsinin genişliyinin də gerçək ifadədəsidir. Bu sahədə mövcud inkişaf səviyyəsinə diqqət edəndə aydın olur ki, muxtar respublika insan amilinin həm də çevik təşkilatçılıq və məşğulluq potensialının təmin edicisi kimi inkişafında maraqlıdır və iqtisadiyyatın sahə strukturunun daha da təşəkkülündə ondan səmərəli istifadə yollarını tapa bilmişdir. $\mathrm{Bu}$ isə təbii $\mathrm{ki}$, makroiqtisadi nailiyyətlərin hərəkətverici qüvvəsi kimi çıxış etməkdədir. Bunu aşağıdakı şəklin məlumatlarından da görə bilərik.

Qeyd edək ki, muxtar respublikanın bütün ümumtəhsil məktəbləri kompüterlə təmin edilmişdir. Hesablamalarla şəhər və rayonların ümumtəhsil məktəbləri üzrə kompüterlərin internetə qoşulması haqqında məlumatı aşağıdakı kimi göstərə bilərik:

Naxçıvan şəhəri $-83,3 \%$;

Şərur rayonu $-88,2 \%$;

Babək rayonu $-87,7 \%$;

Ordubad rayonu $-83,5 \%$;

Culfa rayonu - 94,7\%;

Kəngərli rayonu $-79,5 \%$;

Şahbuz rayonu - 81,9\%;

Sədərək rayonu $-72 \%$. 
Şəkil: 2015-2016-cı tadris ilinin avvalina muxtar respublikanın şəhar va rayonları üzra ümumtahsil maktablarinin İKT ila taminatı

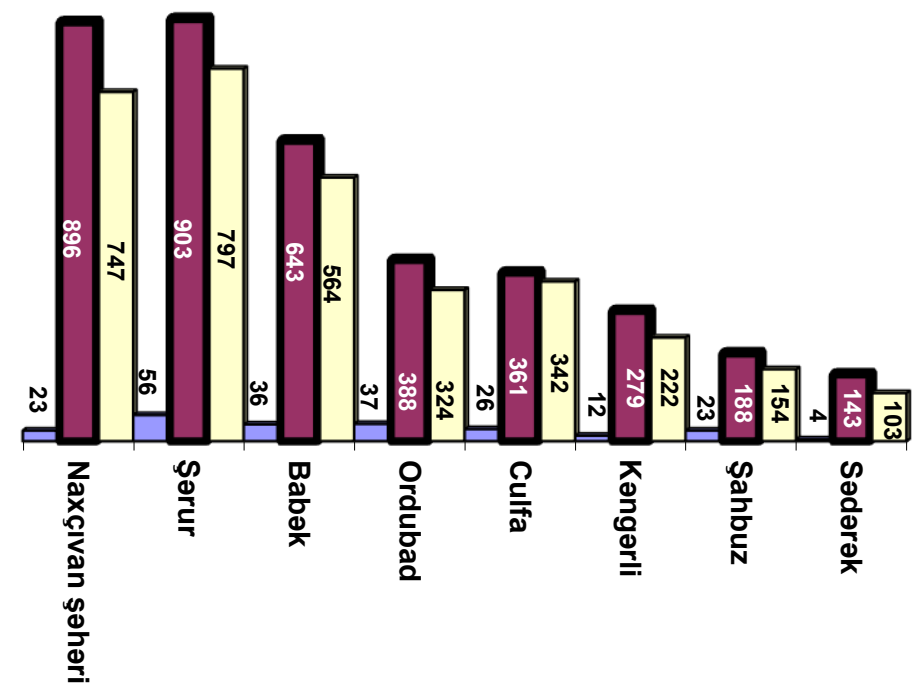

\section{口ümumtəhsil məktəblərin sayı \\ Dümumtəhsil məktəblərində kompüterlərin sayı 口internetə qoşulan kompüterlərin sayı}

Şəkil Naxçıvan MR Dövlat Statistika Komitasinin materialları asasında müalliflar tarafindan hazırlanmışdır (4)

Göründüyü kimi, ümumtəhsil məktəblərində internetdən istifadə üçün səmərəli imkanlar yaradılmış və bu, tədris prosesi üçün bilik mübadiləsinin, telekörpülərin inkişafında, eləcə də əldə edilmiş təcrübələrin yayılmasında mühüm əhəmiyyətə malik olmuşdur. Bu, eyni zamanda ümumtəhsil məktəblərində şagirdlərin kompüterdən istifadə imkanlarını da genişləndir-mişdir. Qeyd edə bilərik ki, müvafiq dövr üzrə orta hesabla:

Naxçıvan şəhərində - 13

Şərur rayonunda -10 
Babək rayonunda -12

Ordubad rayonunda -13

Culfa rayonunda -13

Kəngərli rayonunda -11

Şahbuz rayonunda -11

Sədərək rayonunda - 9 şagird bir kompüterdən istifadə edə bilir (http://www.statistika.nmr.az/).

\section{Gənclər və Dünya Görüsş}

Göstərilən sahələr üzrə tədbirlər özünün ardıcıllı̆̆1, yeni inkişaf səhiflərinin açılması və müasir dünyanın yeni çağırışları ilə səsləşməsilə önəmini artırmaqdadır. Belə ki, Naxçıvan Muxtar Respublikası Ali Məclisinin Sədri tərəfindən 28 avqust 2017-ci il tarixdə Oxunması zəruri olan kitablar haqqinda Sərəncam imzalandı və Oxunması zəruri olan kitabların Siyahısı təsdiq edildi. $\mathrm{Bu}$ tənzimlənmə aktı muxtar respublikada:

- xüsusən gənclərin savadlanmasında güclü və mükəm-məl bazanı daha da möhkəmlətməklə, onlara dünya görüşlərini artırmaqda yeni imkanlar açacaq;

- gənclərlə yanaşı, həm də digər təbəqələrdən və yaşlardan olan insanların asudə vaxtlarının daha səmərəli keçirilməsinə zəmin yaradacaq $\mathrm{ki}$, bu da təhsilə və savadlanmaya olan marağın daha da artmasina səbəb olacaq;

- ölkənin qeyri-maddi istehsal sahəsindəki artım göstəricilərinin yüksəldilməsinə yol açacaq;

- cəmiyyətdə humanizmin, xoşməramın, elmi-mədəni mühitin bundan sonrakı inkişafına və bu istiqamətdə məqsədyönlülüyə təkan olacaq;

- gənclərin yaradıcılıq potensialının, yeni təşəbbüs və təşkilatçlıq keyfiyyətlərinin inkişafına stimul verəcək $\mathrm{ki}$, bu da sosialyönümlülüyü ilə milli iqtisadiyyatın əsas perspektivlərinə hesablanıb. 
Siyahıya diqqət edərkən ilkin, başlanğıc mərhələ üçün 30 kitabın təsdiq edildiyini və onun daha da zənginləşməsinin diqqətdə saxlanılması müəyyən olunduğunu görürük. Təbii ki, bu, Azərbaycan ədəbiyyatının klassik və müasir səhifələrinin açılması, öyrənilməsi, təkrarlanması, bilik və elmi-nəzəri təcrübənin mənimsənilməsi, şair, yazıçı və mütəfəkkirləimizin həyat və yaradıcılı̆̆ına daha yaxından bələdçiliyin ən gerçək göstəricisidir. Digər tərəfdən, Azərbaycan oxucusunun dünya ədəbiyyatına inteqrasiyasının, bununla da dünyəvi bilik və düşüncənin, fikir mübadiləsinin müasir yanaşma tərzinin dolğunluğunun isbatıdır. Burada həm də, sanki, oxunan kitabların müəllifləri ilə qurulan ünsiyyətin real gerçəklikdəki mənzərəsi təqdim edilməkdədir.

Təcrübə göstərir ki, gənc nəslin savadlanması, elmi biliklərinin artırılması və bu sahədəki dünyagörüşünün yüksəldilməsi ölkələrin iqtisadi potensialının hərəkətverici qüvvəsinə çevrilə bilir. Aparıcı və daha çevik olan, bununla da dövlətin gənclər siyasətinin səmərəli təşkilinə təminat verən bu amil iqtisadiyyatın ənənəvi sahələrinin davamlı inkişafı ilə yanaşı, həm də prioritet seçilən istiqamətlərində də perspektivliyinə təminat vermiş olur, bu sahədəki iş qüvvəsinin yüksək potensiallığına zəmin hazırlayır. Məlumdur ki, ölkəmiz milli iqtisadiyyatın perspektivlərini üstün tutaraq iqtisadiyyatın sahə strukturunun, o cümlədən prioritet hesab edilən turizm sektorunun məhsuldarlığına stimul verir. Araşdırmalardan aydın olur $\mathrm{ki}$, gənc və təhsilli iş qüvvəsinin varlığı və güclü dövlət dəstəyi turizm sahəsində böyük fürsətlər təmin etməkdədir (Bingöl Z., 2013, s 23)

Düşünürük ki, Naxçıvan Muxtar Respublikasında gənclərin müasir milli düşüncə tərzinin formalaşmasına stimul verəcək və buna xidmət edəcək tədbirlər onun dövlət siyasətinin çox mühüm tərkib hissəsinə çevrilmişdir. İstər iqtisadiyyatın çox müxtəlif sahələrində, istərsə də dövlət idarəçiliyinin davamlı inkişafında bunun məhsuldar nəticələrini görməkdəyik. Milli-iqtisadi məqsədlərin gerçəkləşməsi və maraqların üstün tutulması gənclərin sosial-psixoloji keyfiyyətlərinin ən gerçək ifadəsinə yol açmışdır. Bu mənada qeyd olunanlar ümumilikdə ölkəmiz miqyasında hüquqi və iqtisadi tənzimləmələrdə gənclərin çoxşaxəli fəaliyyətinin təmin edilməsi üçün əlverişli şəraitin yaradılmasına münbit zəmin yaratmaqdadır. 


\section{Netice}

Beləliklə, qeyd edilənlərin ümumiləşdirilməsindən belə qənaətə gəlirik ki, Naxçıvan Muxtar Respublikası:

- gənclərin dünya görüşünün və elmi potensialının daha da artırılmasında, bu sahədəki təcrübi biliklərinin gücləndirilməsindəki islahatların davam etdirilməsində qərarlı və qətiyyətlidir;

- ölkə iqtisadiyyatının sosiallaşması sahəsində yeni bir mərhələ başlatmaqdadır;

- Azərbaycan iqtisadiyyatının uzaq gələcək üçün inkişaf perspektivlərinin müəyyənləşdirilməsini, sosial dayanıqlığının gücləndirilməsini, ictimai fikrin və hadisə və proseslərə dürüst yanaşmanın daha da sağlamlaşdırılmasını, ədəbiyyatının zənginləşməsini, ziyalı mühitinin daha da inkişafını, elmi araşdırmaların stimullaşdırılmasını, tədris prosesinin səmərəli idarə olunmasını sürətləndirməkdədir;

- milli iqtisadiyyat quruculuğunda ixtisaslaşmış kadr potensialının formalaşmasında gənclərin hərəkətverici qüvvəyə çevrilməsini təmin etməkdədir;

- prioritet olaraq seçilən istiqamətlərin inkişafında çevik amillərin səfərbər edilməsində gənclərin rolunun daha da artırılması təmin edilməkdədir və s.

\section{ӘDӘBIYYYAT}

Azərbaycan Respublikası Dövlət Statistika Komitəsi (2004). Osas iqtisadistatistik göstəricilərə dair metodoloji izahatlar. Bakı: Səda,137

Bingöl, Z, (2013). Government support for the development of tourism in the Mediterranean Region. Journal of Education and Sociology, 4(2), 16-20. DOI: 10.7813/jes.2013/4-2/3

Ohmədov N.H. (2008). Naxçıvan Muxtar Respublikasının prioritetləri: iqtisadi artım, dinamik inkişaf. Naxçıvan: Sabah, 431

Libman Q.I., Filatov O.K. (1989) tərtibatında. Qısa iqtisadi lüğət. Bakı: ASE, 359 
Müstəqilliyimizin on ili. Naxçıvan Muxtar Respublikası 1991-2001-ci illər ərzində. Naxçıvan: Әcəmi, 2001, 92

Naxçıvan Muxtar Respublikası 75 (1999), yubiley-statistik məcmuə. Naxçıvan, 96

Qasımov C.Y. (2017), İqtisadi terminologiya: aqrar sektor, məşğulluq, sosial sfera. Naxçıvan: Әcəmi, 104

Qasımov C.Y., Oləsgərova F.Q. (2017) Naxçıvan Muxtar Respublikasının sosial-iqtisadi inkişafı: tarixilik və müasirlik. Dərs vəsaiti. Naxçıvan: Ocəmi, 186

http://www.statistika.nmr.az, 15.11.2017

http://www.e-qanun.az, 15.11.2017

\section{Kaynakça Bilgisi / Citation Information}

Oləsgərova, F. ve Qasımov, C. (2018). Naxcıvan muxtar respublikasında dövlət gənclik siyasətinin əsasları. OPUS - Uluslararası Toplum Araştırmalan Dergisi, 8(Gençlik Araştırmaları Özel Sayısı), 441-452. 